\title{
Investigation of the Levels of Animal and Empatic Trends in the Football Elements
}

\author{
Ömer Sülün and Dr. Hasan ŞAHAN
}

\begin{abstract}
The aim of this research is to examine the levels of anger and empathetic tendencies of football referees who serve in the Istanbul Region in Turkish Professional Football Leagues. The sample of the research includes 82 football referees ( 80 male, 2 female) serving in the İstanbul region during 2011-2012 football season. As data collection tools in the research; Referee Personal Information Form, created by the researcher, a state of trait anger scale adapted to Turkish by A. Kadir Özer(1), and The Empathy Tendency Scale (1988) developed by Üstün Dökmen (2) were used. According to the results of the research; At which level the referees referee, By year variable, By educational level, According to refereeing careers, It was found that there was no meaningful relationship between Persistent Anger and Anger and Empathic Tendency Levels( $p>0,05)$. According to the results of the study, there is no significant difference among referees regarding their ability to judge in the sense of trait anger levels and anger and empathetic tendency levels by year variable $(p>0,05)$. In addition, different samples and different cultures are examined. It is thought that this issue will contribute to the literature of Turkish sports psychology by carrying out more extensive researches.
\end{abstract}

Index Terms - Empathy, Anger, Referee

\section{INTRODUCTION}

Sport cannot be defined as just a game seen at football pitch but rather it has transformed into a commercial activity which is driven by sponsors and sports markets, and national and international competitions are experienced through it (3). Televisions, sponsors and in a more broad sense multinational corporations, which have both football clubs and television channels, are spending huge amounts of money every year because of its superiority and universality. Football, which is a very profitable business being worth 1,500 billion francs in 1998, offers ever-growing opportunities, and promises huge income (4).

The successes or failures of the clubs determine the developments in this big market and in this point the performances of referees, who conduct the competitions, is an important discussion subject, particularly in Turkey. In this sense, conducting a football competition properly has become a phenomenon which not only affects players, managers and spectators but also give birth to unimagined economic results. Sometimes millions and sometimes hundreds of millions of people watch this sport and the control of it in the pitch is performed by football referees taking sports education (5).

Ömer Sülün, Graduate student, Karamanoğlu Mehmetbey University.

Dr. Hasan ŞAHAN, Akdeniz university, Spor Bilimleri Fakültesi, Antalya, Turkey. E-mail- hasansahan@akdeniz.edu.tr
Football refereeing is a physical act which has psychological and cognitive (mental) aspects. The referee who becomes aware of the event should decide within a very short period of time. In short, the referee selects, analyzes, categorizes, compares, and then gives the most appropriate response to the stimulus by identifying it (6).

Referees are exposed to several pressures inside and outside the football pitch. After each competition, he or she is declared as a scapegoat, considered as responsible person or put the blame on, and most importantly various comments related to their personalities are made. All these developments have negative psychological and mental effects on referees.

In the presence of various negative reactions that football referees encounter before, during and after the competition, they would control their anger and empathize with others which leads them to fulfill their tasks successfully. Being stopped by someone from doing something (not fulfilling the request), being ignored, humiliated, confronted with arbitrary behavior (getting a raw deal) and getting attacked (suffering from an psychological affront; getting attacked physically) are some of the most outstanding causes that make people angry. Any situation, event or person, which block someone from achieving his or her goals or meeting his or her needs, is the foremost cause leading to the feeling of anger. (7).

The concept of empathy, which determines success in human relations and directs social relations, is considered an important and necessary skill that protects the understanding of society. For this reason, one of the qualities that referees, conducting football matches, need to have is the ability to empathize.

This study was carried out to compare the levels of Anger and Furiousness and the levels of Empathetic Tendencies of. 82 football referees serving in the İstanbul region during 2011-2012 football season. It is seen that $80 \%$ of the referees in our subject group are in the age range of $26-32$, and $75 \%$ of the referees are at least 7-14 years in service. The comparison of the levels of anger and furiousness and empathetic tendencies of referees serving in Turkish professional football league from the Istanbul region will provide a better explanation of the behaviors exhibited by referees.

The State Trait Anger Scale (STAS) originally developed by CD Spielberger in 1983 and the Trait Anger - Anger Scale (SÖ-ÖTÖ) adopted to Turkish by AK Özer in 1994 was used in order to determine the trait anger and anger styles which were dependent variables in this research. The scale used for determination of anger and anger styles in adolescents and adults consists of a total of 34 items and 4 sub-dimensions. Sub dimensions of the scale are; Trait Anger (10 items), Anger in (8 items), Anger Out (8 items) and Anger control (8 items). Firstly, 
the personal information of the referees, the persistent anger and anger style and the Empathetic Tendency Scale were transferred to the data file created on the computer. The average of the scores, the standard deviation, the minimum and maximum values were calculated. Correlation analyzes were done. One-way ANOVA test was used in comparison between groups of parameters in the case of more than two groups. The results were found to be $0.95 \%$ confidence interval according to ANOVA test and significance was found to be bi-directional at $\mathrm{p}<0.05$.

As seen in Table 1, it was found that there was no significant difference between the Levels of Trait Anger Style and the serving levels of referees [f value $=0.489 \mathrm{p}=0.815 \& \mathrm{gt}$; 0.05]. According to the serving level of referees, it was determined that the difference between the subordinate levels of anger was not significant [ $\mathrm{f}$ value $=1,394 \mathrm{p}=0,228>0.05$ ]. According to the serving level of referees, it was determined that the difference between the subordinate levels of anger was not significant [ $f$ value $=1,444 \mathrm{p}=0,228>0.05$ ]. The level of anger control, according to the serving level of referees, was not found to be significant [ $\mathrm{f}$ value $=0.502 \mathrm{p}=0.896>0.05$ ]. It was determined that there was no significant difference between the Empathic Tendency levels, according to the serving level of referees. [f value $=0.474 \mathrm{p}=0.826>0.05$ ]

As seen in Table 2; the level of trait anger style according to the year variable, the difference was not statistically significant [ $\mathrm{F}$ value $=0.224 \mathrm{p}=0.879>0.05]$. According to the year variable, the difference between anger and external sub-levels was not significant $[\mathrm{F}$ value $=0.993 \mathrm{p}=0.401>0.05]$. It was found that the difference between the levels of anger control according to the year variable was not significant. $[\mathrm{F}$ value $=$ $1,198 \mathrm{p}=0,316>0.05]$. It was determined that the difference between the levels of empathetic tendencies of referees according to the year variable was not significant $[\mathrm{F}$ value $=$ $0.140 \mathrm{p}=0.936>0.05]$.

When Table 3 was examined, there was no significant relationship between empathetic tendency and persistent anger levels $(r=-0,075 \mathrm{p}>0,05)$. There was no significant relationship between empathetic tendency and subordinate levels of anger $(\mathrm{r}$ $=-0,134 \mathrm{p}>0,05)$. There was no significant relationship between empathetic tendency and external sub levels of anger $(\mathrm{R}=$ $-0,017 \mathrm{p}>0,05)$. There was no significant relationship between empathetic tendency and anger control levels $(r=-0,114 \mathrm{p}>$ $0,05)$.

TAble 1. One Way Anova Results Showing the LeVels of Trait ANGer And ANGer Style and Empathetic Tendency AcCording to Referees' LeVel OF SERVING AT THE FIEL

\begin{tabular}{|c|c|c|c|c|c|c|}
\hline & Variance Source & KT & Sd & KO & $\mathbf{F}$ & $\mathbf{P}$ \\
\hline \multirow[t]{2}{*}{ Trait Anger } & Between groups & 55,752 & 6 & 9,292 & \multirow[t]{2}{*}{0,489} & \multirow[t]{2}{*}{0,815} \\
\hline & In-group & 1426,199 & 75 & 19,016 & & \\
\hline \multirow[t]{2}{*}{ Anger Inner Sub } & Between groups & 80,108 & 6 & 13,351 & \multirow[t]{2}{*}{1,394} & \multirow[t]{2}{*}{0,228} \\
\hline & In-group & 718,440 & 75 & 9,579 & & \\
\hline \multirow[t]{2}{*}{ Anger Out Sub } & Between groups & 108,660 & 6 & 18,110 & \multirow[t]{2}{*}{1,444} & \multirow[t]{2}{*}{0,209} \\
\hline & In-group & 940,315 & 75 & 12,538 & & \\
\hline \multirow[t]{2}{*}{ Anger Control } & Between groups & 116,250 & 6 & 19,375 & \multirow[t]{2}{*}{0,896} & \multirow[t]{2}{*}{0,502} \\
\hline & In-group & 1621,750 & 75 & 21,623 & & \\
\hline \multirow{2}{*}{$\begin{array}{l}\text { Empathetic } \\
\text { Tendency }\end{array}$} & Between groups & 213,763 & 6 & 35,627 & \multirow[t]{2}{*}{0,474} & \multirow[t]{2}{*}{0,826} \\
\hline & In-group & 5641,798 & 75 & 75,224 & & \\
\hline
\end{tabular}




\begin{tabular}{|c|c|c|c|c|c|c|}
\hline & $\begin{array}{l}\text { Variance } \\
\text { Source }\end{array}$ & KT & Sd & KO & $\mathbf{F}$ & $\mathbf{P}$ \\
\hline \multirow[t]{2}{*}{ Trait Anger } & Between groups & 12,666 & 3 & 4,222 & \multirow[t]{2}{*}{0,224} & \multirow[t]{2}{*}{0,879} \\
\hline & In-group & 1469,286 & 78 & 18,837 & & \\
\hline \multirow[t]{2}{*}{ Anger Inner Sub } & Between groups & 64,922 & 3 & 21,641 & \multirow[t]{2}{*}{2,301} & \multirow[t]{2}{*}{0,084} \\
\hline & In-group & 733,627 & 78 & 9,405 & & \\
\hline \multirow[t]{2}{*}{ Anger Out Sub } & Between groups & 38,579 & 3 & 12,860 & \multirow[t]{2}{*}{0,993} & \multirow[t]{2}{*}{0,401} \\
\hline & In-group & 1010,397 & 78 & 12,954 & & \\
\hline \multirow[t]{2}{*}{ Anger Control } & Between groups & 76,528 & 3 & 25,509 & \multirow[t]{2}{*}{1,198} & \multirow[t]{2}{*}{0,316} \\
\hline & In-group & 1661,472 & 78 & 21,301 & & \\
\hline \multirow[t]{2}{*}{ Empathetic Tendency } & Between groups & 31,339 & 3 & 10,446 & \multirow[t]{2}{*}{0,140} & \multirow[t]{2}{*}{0,936} \\
\hline & In-group & 5824,222 & 78 & 74,670 & & \\
\hline
\end{tabular}

TABLE 3. CORRELATION RESULTS BETWEEN REFEREES TRAIT ANGER AND ANGER STYLE LEVELS AND EMPATHETIC TENDENCY LEVELS
\begin{tabular}{|c|c|c|c|c|c|}
\hline & Trait Anger & $\begin{array}{c}\text { Anger } \\
\text { Inner Bottom }\end{array}$ & $\begin{array}{c}\text { Anger Out } \\
\text { Under }\end{array}$ & Anger Control \\
\hline $\begin{array}{r}\text { Empathetic } \\
\text { Tendency }\end{array}$ & $\mathrm{r}$ & $-0,075$ & 0,134 & 0,017 & 0,114 \\
\cline { 2 - 6 } & $\mathrm{p}$ & 0,505 & 0,229 & 0,879 & 0,307 \\
\cline { 2 - 6 } & $\mathrm{n}$ & 82 & 82 & 82 & 82 \\
\hline
\end{tabular}

\section{II.DISCUSSION AND CONCLUSION}

According to in which level referees serving, Trait Anger Style levels was not found to be significant [ $\mathrm{f}$ value $=0,489$ $\mathrm{p}=0,815>0.05]$. According to the serving level of referees, it was determined that the difference between the subordinate levels of anger was not significant [ $\mathrm{f}$ value $=1,394$ $\mathrm{p}=0,228>0.05]$. According to the serving level of referees, it was determined that the difference between the subordinate levels of anger was not significant [ $\mathrm{f}$ value $=1,444$ $\mathrm{p}=0,228>0.05]$. The level of anger control, according to the serving level of referees, was not found to be significant [f value $=0.502 p=0.896>0.05]$. It was determined that there was no significant difference between the Empathetic Tendency levels, according to the serving level of referees [ $f$ value $=0,474$ $\mathrm{p}=0,826>0.05]$. The level of trait anger style according to the year variable, the difference was not significant [ $\mathrm{f}$ value $=0.224$ $\mathrm{p}=0.879>0.05]$. According to the year variable, the difference between anger and external sub-levels was not significant $[\mathrm{f}$ value $=0,224 \mathrm{p}=0,879>0.05]$. According to the year variable, the difference between anger and external sub-levels was not significant [ $\mathrm{F}$ value $=0.993 \mathrm{p}=0.401>0.05]$. It was found that the difference between the levels of anger control according to the year variable was not significant. [ $\mathrm{F}$ value $=1,198 \mathrm{p}=$ $0,316>0.05]$. It was determined that the difference between the levels of empathetic tendencies of referees according to the year variable was not significant [F value $=0.140 p=0.936>0.05$ ]

There was no significant relationship between empathetic tendency and persistent anger levels $(r=-0,075 p>0,05)$. There was no significant relationship between empathetic tendency and subordinate levels of anger $(r=-0,134 p>0,05)$. There was no significant relationship between empathetic tendency and external sub levels of anger $(R=-0,017 p>0,05)$. There was no significant relationship between empathetic tendency and anger control levels $(r=-0,114 \mathrm{p}>0,05)$. As a result, it was determined that there was no significant difference between the anger tendencies of the subjects in this study and the empathy associations. In particular, it is really an important issue to support such a difficult activity, which is the concept of refereeing, with different studies and to minimize the problems that may arise in the field.

\section{REFERENCES}

[1] Özer, A.(1994). “Sürekli Öfke ve Öfke İfade Tarzı Ön Çalışması”, Türk Psikoloji Dergisi, Cilt:9, Sayı:31, Sayfa: 26-35, Ankara) 
[2] Dökmen, Ü. (1988). Empatinin Yeni Bir Modele Dayanılarak Ölçülmesi ve Psikodrama ile Geliştirilmesi, Ankara Üniversitesi Eğitim Bilimleri Fakültesi Dergisi, 21(1-2), 155-190)

[3] Şen, H. (2006). Endüstrileşen Futbol ve Bir Toplumsal Sorun Olarak Futbolda Şiddet. 9.Uluslararası Spor Bilimleri Kongresi -Muğla

[4] Chiristian, A. (2002). Futbol A.Ş. (Çev. Ali Berktay) İstanbul: Kitap Yayınevi

[5] Sunay, H. (1992). Ankara Bölgesi Futbol Hakemlerinin Hakemliğe Yönelmelerine Etki eden Motivasyonel Etkenler Üzerine Bir Araştırma. H.Ü. Futbol Bilim ve Teknoloji Dergisi, 18-23.

[6] Cel, A. (1994). Hakemlik Psikolojisi. Futbol Bilim ve Teknoloji Dergisi, çeviren: Kin A, 1,21-23, Ankara)

[7] Atkinson, R.L., Smith, E.E., Bem, D.J. \& Nolen-Hoeksema, S.Hilgard's(1996) "Introduction to Psychology", Harcourt Brace Company, New York, 1996 